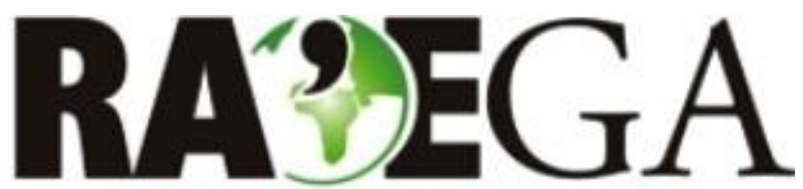

O ESPAÇO GEOGRÁFICO EM ANÁLISE

WATER BALANCE BASED ON REMOTE SENSING DATA IN PANTANAL BALANÇO HÍDRICO NO PANTANAL USANDO DADOS DE SENSORIAMENTO REMOTO

Adriana Aparecida Moreira ${ }^{1}$, Alice César Fassoni-Andrade ${ }^{1}$, Anderson Luis Ruhoff ${ }^{1}$, Rodrigo Cauduro Dias de Paiva ${ }^{1}$

\begin{abstract}
Pantanal, located in the Upper Paraguay basin, is the world's largest tropical wetland. The maintenance of this ecosystem depends on the water balance since precipitation is seasonal and high losses of water occur due to the high evapotranspiration. Water balance assessment using in situ data is still a challenge due to the large extension of the area and the complexity to be represented. In this study, the water balance in the Upper Paraguay basin was investigated based on hydrological variables derived from remote sensing data. Precipitation, evapotranspiration, and water storage change data were estimated with accuracy by the water balance, but the same was not possible for the discharge. However, high uncertainties in the estimates were verified, mainly during the rainy season. The remote sensing data allowed the identification of the seasonality of hydrological variables in the Pantanal system and in the different regions of the basin: Chaco, Pantanal and Planalto. Water deficit in the basin was observed from March/April to September as well as a positive water balance due to precipitation during the rest of the year. The spatial analysis of the basin showed that in the northern region, the precipitation, the evapotranspiration, and the water storage variation are higher than in the southern region. Results demonstrated that remote sensing data can help in the comprehension of hydrological systems operation, especially in large wetland regions.
\end{abstract}

Keywords: Evapotranspiration; GRACE; Wetlands; Water regime.

\title{
RESUMO
}

O Pantanal, localizado na bacia do Alto Paraguai, é a maior área de wetlands do mundo. A manutenção desse ecossistema depende do balanço hídrico uma vez que a precipitação é sazonal e altas perdas de água ocorrem devido às elevadas taxas de evapotranspiração. Analisar o balanço hídrico utilizando dados in situ ainda é um desafio devido à grande extensão da área e toda sua complexidade a ser representada. Neste estudo o balanço hídrico na bacia do Alto Paraguai foi investigado utilizando variáveis hidrológicas baseadas em sensoriamento remoto. Dados de precipitação, evapotranspiração e variação do armazenamento da água foram estimados com boa acurácia pelo balanço hídrico, entretanto, o mesmo não foi possível para a estimativa da vazão. Altas incertezas nas estimativas foram verificadas, principalmente durante o período chuvoso. Estimativas de sensoriamento remoto demonstram a sazonalidade das variáveis hidrológicas no sistema Pantanal e nas diferentes regiões da bacia: Chaco, Pantanal e Planalto. Foi observado déficit de água na bacia de março/abril até setembro e um saldo positivo nos meses restantes do ano devido à precipitação. A análise espacial da bacia mostrou que na região norte a precipitação, a evapotranspiração e a variação do armazenamento da água são maiores que na região sul. Os resultados deste estudo demonstraram que os dados de sensoriamento remoto podem ajudar na compreensão do funcionamento de sistemas hidrológicos, principalmente em regiões de grandes áreas úmidas.

Palavras chave: Evapotranspiração; GRACE; Áreas úmidas; Regime hídrico.

\footnotetext{
1 Universidade Federal do Rio Grande do Sul (UFRGS). emails: \{moreiradriana00, alice.fassoni, andersonruhoff, rodrigocdpaiva\}@gmail.com
} 


\section{REMOTE SENSING OF WATER BALANCE IN PANTANAL}

\section{INTRODUCTION}

The Upper Paraguay Basin covers Bolivia, Paraguay, and Brazil in South America. It has one of the largest wetland areas in the world: the Pantanal. This region has a flat relief and mild slope, resulting in very slow and large flooded areas (TUCCl et al., 1999). Hamilton et al. (1996) showed that Pantanal flooded areas range between 11,000 and $110,000 \mathrm{~km}^{2}$ (total area of $137,000 \mathrm{~km}^{2}$ ). Due to large flooded areas and high temperatures over the year, the annual potential evapotranspiration is higher than annual precipitation in this region (BORDAS, 1996; TUCCI et al., 1999). The Pantanal annual flood affects Paraguay River' hydrodynamics located downstream (PAZ et al., 2010), and influences the region's biodiversity (HAMILTON, 2002).

Remote sensing observations are a promising alternative to obtain spatial-temporal hydrological variables estimates, such as precipitation, evapotranspiration (ET), and terrestrial water storage changes since in situ hydrological cycle components measurements do not have enough density to cover large scales and all of the surface's heterogeneity. This fact is especially important for ET measurements, which represent a crucial nexus between the hydrological energy, and carbon cycles (Fisher et al., 2017). Furthermore, there are few measurement sites, insufficient to cover all existing spatial and climatic heterogeneity.

Since 2002, global terrestrial water storage changes (TWSC) can be obtained from Gravity Recovery and Climate Experiment (GRACE) mission (LANDERER and SWENSON, 2012; TAPLEY et al., 2004; SWENSON and WAHR, 2006). Furthermore, precipitation and ET data can be obtained from several satellite databases and combined or not with observed or/and reanalysis data.

Several studies have evaluated the potential water balance based on remote sensing (MAEDA et al., 2017; OLIVEIRA et al., 2014; PENATTI et al., 2015; RODELL et al., 2004, 2011; SENAY et al., 2011; SHEFFIELD et al., 2009; SWANN and KOVEN, 2017; ZHANG et al., 2018). Generally, these studies have suggested that although the water balance closure is still a challenge, the obtained estimates offer valuable information about hydrological cycle variables.

Penatti et al. (2015) evaluated the potential use of remote sensing data for the quantification of monthly water balance in the Upper Paraguay Basin. The spatial and temporal aspects of the water balance components and their closure were evaluated using GRACE TWSC, tropical rainfall measuring mission (TRMM) precipitation and MOD16 ET data. The results showed that, despite the low spatial resolution, the GRACE anomalies corresponded to the large floods and droughts, as well as the consistent relationship with the water balance components and with the vegetation greenness evaluated through Enhanced vegetation index.

The evaluation of remote sensing data as an alternative to the hydrological can still present many challenges, like choosing the best database of variables estimated in regions with marked characteristics, such as wetland. In this regard, this study aimed to evaluate the water balance variables estimated by remote sensing in the Upper Paraguay Basin, such as precipitation, evapotranspiration and water storage changes, as well as the uncertainties of the estimates of these variables.

\section{STUDY AREA}

The Upper Paraguay Basin has three distinct regions, the Chaco, located in the west and characterized by low annual rainfall, and the Planalto and Pantanal regions, characterized by high precipitation rates (Figure 1). The Planalto region has high lands (over $200 \mathrm{~m}$ ) with annual rainfall around $1,400 \mathrm{~mm}$ and quick-waterdrainage (TUCCl et al, 1999). The Pantanal region, located in the center of the basin, has slow drainage due to its low slope, which contributes to the formation of large flood areas. 


\section{REMOTE SENSING OF WATER BALANCE IN PANTANAL}

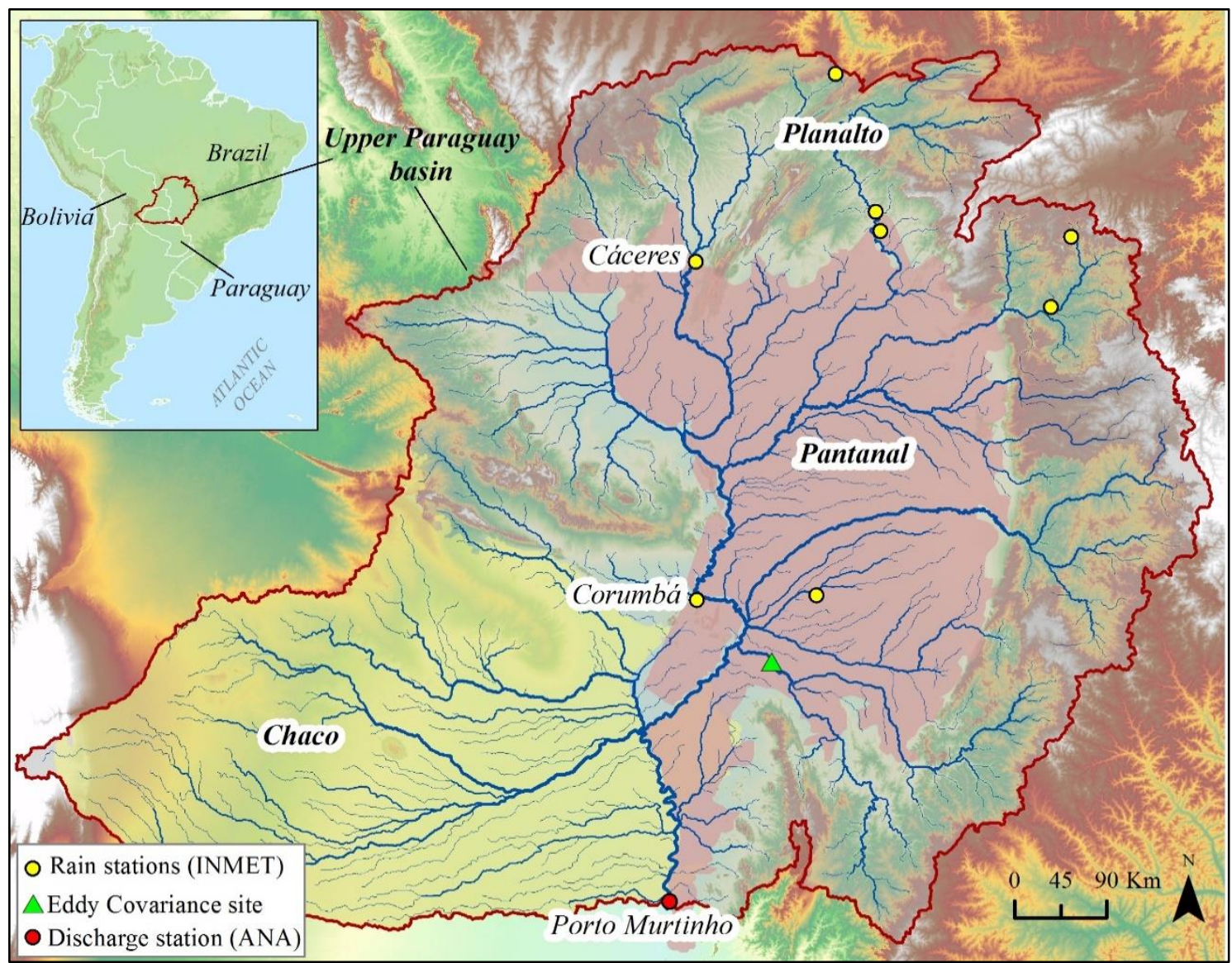

Figure 1 - Upper Paraguay Basin location delimited by Porto Murtinho discharge station, from National water agency (ANA). Rain gauges station in Cárceres and Corumbá from National Institute of Meteorology. Chaco region is in yellow, Pantanal region in rose and Planalto region in light gray.

The rain station shows the highest values from November to March and is more prominent in the northern region than in the southern region. The seasonal flooding in Pantanal happens due to the overflow of River water. In some areas, it happens due to local rainfall. According to Hamilton et al. (1996), the flood pulse has a delay of two to six months after maximum rainfall (January) depending on the region (two months in the northern and four to six months in the southern). However, the largest flooded area in Pantanal occurs in March and April, two and three months after the maximum rainfall, which occurs in January.

During the dry season, the water stored in the floodplain is decreased by infiltration losses and mainly evaporation due to high temperatures over the year (TUCCl et al., 1999). According to Ponce (1996), the basin runoff coefficient ranges between $7 \%$ and $14 \%$ so that in an average year, the runoff in basin outlet is equivalent to that of the precipitation percentage.

\section{WATER BALANCE APPROACH}

In order to estimate the monthly water balance in the Upper Paraguay Basin (Equation 1), precipitation (P), ET and, TWSC were used based on remote sensing. ( $Q$ ) data was discharged from Porto Murtinho station, obtained by National water agency (ANA) (code 67100000 and area $576,000 \mathrm{~km}^{2}$ ).

\section{Equation 1:}

$$
T W S C=P-E T-Q
$$

There is a great potential for using GRACE data in hydrological studies because temporal continental gravitational fields are mainly 


\section{REMOTE SENSING OF WATER BALANCE IN PANTANAL}

attributed to changes in terrestrial water storage (SHEFFIELD et al., 2009; RODELL et al., 2011). These data are available in three processing centers: (i) GeoForschungsZentrum (GFZ), in Potsdam, Germany; (ii) Center of Space Research (CSR), Texas University at Austin - USA; (iii) Jet Propulsion Laboratory (JPL), of the National Aeronautics and Space Administration. Thus, terrestrial water storage data were obtained by means of the simple average of these three GRACE data solutions.

Monthly estimates were used by MultiSource Weighted-Ensemble precipitation (MSWEP) version 2.1 (BECK et al., 2017b), $0.1^{\circ}$ of spatial resolution. The MSWEP precipitation is derived from a combination of multiple highquality precipitation datasets, including in situ measurements, satellites observations and reanalysis data (BECK et al., 2017b). ET data are from Global Land Evaporation Amsterdam Model (GLEAM), version 3.2b (MIRALLES et al., 2011), in a daily temporal and $0.25^{\circ}$ of spatial resolution. GLEAM aims to estimate the daily terrestrial evaporative fluxes based on the Priestley and Taylor equation (PRIESTLEY and TAYLOR, 1972), mainly using remote sensing observations. All datasets were converted, to mm.month ${ }^{-1}$ when necessary, considering the study period from January 2003 to December 2014.

To evaluate the water balance in the Upper Paraguay Basin, we used monthly averages between two time steps ( $t$ ) observations of precipitation, ET and discharge variables (Equation 2) (RODELL et al., 2011, 2004; SHEFFIELD et al., 2009).

Equation 2:

$$
\begin{aligned}
& T W S C=\frac{P_{(t+1)}+}{2}-\frac{E T_{(t+1)}+E T_{t}}{2} \\
&-\frac{Q_{(t+1)}+Q_{t}}{2}
\end{aligned}
$$

where $S$ is the terrestrial water storage.

Considering that GRACE anomalies of terrestrial water storage are available at irregular time intervals, the storage changes were calculated as the difference between two points of the GRACE data, representing the average variation of the terrestrial water storage (LONG et al., 2014; OLIVEIRA et al., 2014) (Equation 3).

\section{Equation 3:}

$$
\frac{d S}{d t} \approx \frac{T W S}{d t} \approx \frac{T W S_{t+1}-T W S_{t}}{\Delta t}
$$

where TWS is the terrestrial water storage change in the $t$ time.

The estimation uncertainties in each variable as residue of the water balance equation were also analyzed considering a 95\% confidence interval. For this estimate, it was considered that the errors are independent and normally distributed. Therefore, relative uncertainty can be obtained as the quadratic sum of the errors of each variable, as exemplified in Equation 4 for the (dS)/dt (RODELL et al., 2011, 2004; SENAY et al., 2011; SHEFFIELD et al., 2009).

Equation 4:

$$
v_{d s d t}=\frac{\sqrt{v_{P}^{2} P^{2}+v_{E T}^{2} E T^{2}+v_{Q}^{2} Q^{2}}}{|P-E T-Q|}
$$

where $u$ is the relative uncertainty for each water balance variable.

The precipitation and ET uncertainties data were calculated as the standard deviation of the differences between the observed and estimated data. This included data from rainfall stations and ET data obtained from flux measurement site located in the Pantanal (19 $34^{\prime}$ S; $57^{\circ} 01^{\prime} \mathrm{W}$ ). Further details on this measurement can be found in Oliveira et al. (2006). An uncertainty of $10 \%$ was considered for this discharge, as used by Rodell et al. (2011). The mean of the uncertainties of each rain gauge station was considered for the precipitation uncertainty. In the ET uncertainty analysis, data of the flux measurement site, latent heat flux data (LE in W. $\mathrm{m}^{-2}$ ) to ET (mm.day ${ }^{-1}$ ), dividing LE by the latent heat of liquid water vaporization $(\lambda$ in 


\section{REMOTE SENSING OF WATER BALANCE IN PANTANAL}

MJ.kg-1) (SHUTTLEWORTH, 2012) were used. It was considered a maximum percentage of data failures of $25 \%$ for data composition from 30 minutes to daily ET. As the availability Pantanal site measurements extend from September 2000 to December 2002, the uncertainty analysis was performed considering the daily seasonal mean of the data.

The TWSC uncertainty was also calculated. These data have both measurement and leakage errors. Measurement errors are associated with signal loss due to recovery errors, while leakage errors are related to data processing (LANDERER and SWENSON, 2012; RODELL et al., 2011). By means, Equation 5 TWSC data error was calculated as the square root of the measurement and leakage errors.

Equation 5:
Total error

$$
=\sqrt{\text { Leakage error }^{2}+\text { Measurement error }}{ }^{2}
$$

Finally, statistical metrics were calculated to evaluate the accuracy of the estimated variables through the water balance with those obtained by remote sensing and measurements.

\section{RESULTS AND DISCUSSION}

Figure 2 shows the seasonal behavior of each observed and estimated variable as residual of the water balance (2003 to 2014) in addition to the uncertainty calculated for each variable. It is observed that all variables estimated by the water balance presented a good agreement with the remote sensing data, with correlation coefficient (r) between 0.74 and 0.93 (Table 1 ). In relation to the discharge estimate, it showed high overestimation and a correlation coefficient of 0.26 .

\begin{tabular}{|c|c|c|c|c|}
\hline & $\begin{array}{l}P-E T-Q \text { vs } \\
\text { TWSC GRACE }\end{array}$ & $\begin{array}{l}E T+\text { TWSC + Q vs } \\
P \text { MSWEP }\end{array}$ & $\begin{array}{l}P \text {-TWSC - } Q \text { vs } \\
E T \text { GLEAM }\end{array}$ & $\begin{array}{l}P \text { - ET -TWSC vs } Q \\
\text { measured }\end{array}$ \\
\hline $\mathbf{r}$ & $0.93^{*}$ & $0.91 *$ & $0.74 *$ & $0.26 *$ \\
\hline RMSE (\%) & 37 & 30 & 37 & 279 \\
\hline BIAS (mm.mes $\left.{ }^{-1}\right)$ & 4.39 & -4.86 & 4.86 & \\
\hline
\end{tabular}

Table 1 - Statistical metrics of the water balance estimated by remote sensing (2003-2014). * significant results with a $p$-value $<0.01$.

In general, the uncertainties of the variables estimated by water balance (gray area in Figure 2) are greater than the errors of the observed variables (bars in Figure 2). The calculated uncertainty for the MSWEP precipitation data using measurements of eight rainfall stations was $35.46 \%$, while for the ET GLEAM the uncertainty calculated using data measured in a flux measurement site in the Pantanal was $50.14 \%$, with a correlation

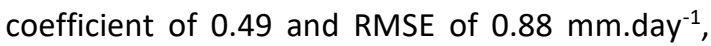
between ET data (GLEAM vs flux measurement site). Finally, in GRACE's estimates of variation of terrestrial water storage, an uncertainty of 35.31 mm.month ${ }^{-1}$ was observed. In general, both the estimates of the water balance variables and of remote sensing showed lower uncertainties during the dry season (May to September). The uncertainties in the water balance's TWSC were around $43.19 \mathrm{~mm}$. month $^{-1}$, but during the rainy season, 59,03 mm.month ${ }^{-1}$ uncertainties were observed and in a dry season, this percentage decreased to 21,01 mm.month ${ }^{-1}$. Regarding precipitation, an uncertainty of $32.87 \mathrm{~mm}$.month 1 for the MSWEP was observed while for the estimation of the water balance, a greater uncertainty was observed: around 49.44 mm. month ${ }^{-1}$. The mean of GLEAM uncertainty was around $38.82 \mathrm{~mm}$.month ${ }^{-1}$ and the water balance was much larger, around $51.13 \mathrm{~mm}$. month $^{-1}$. 


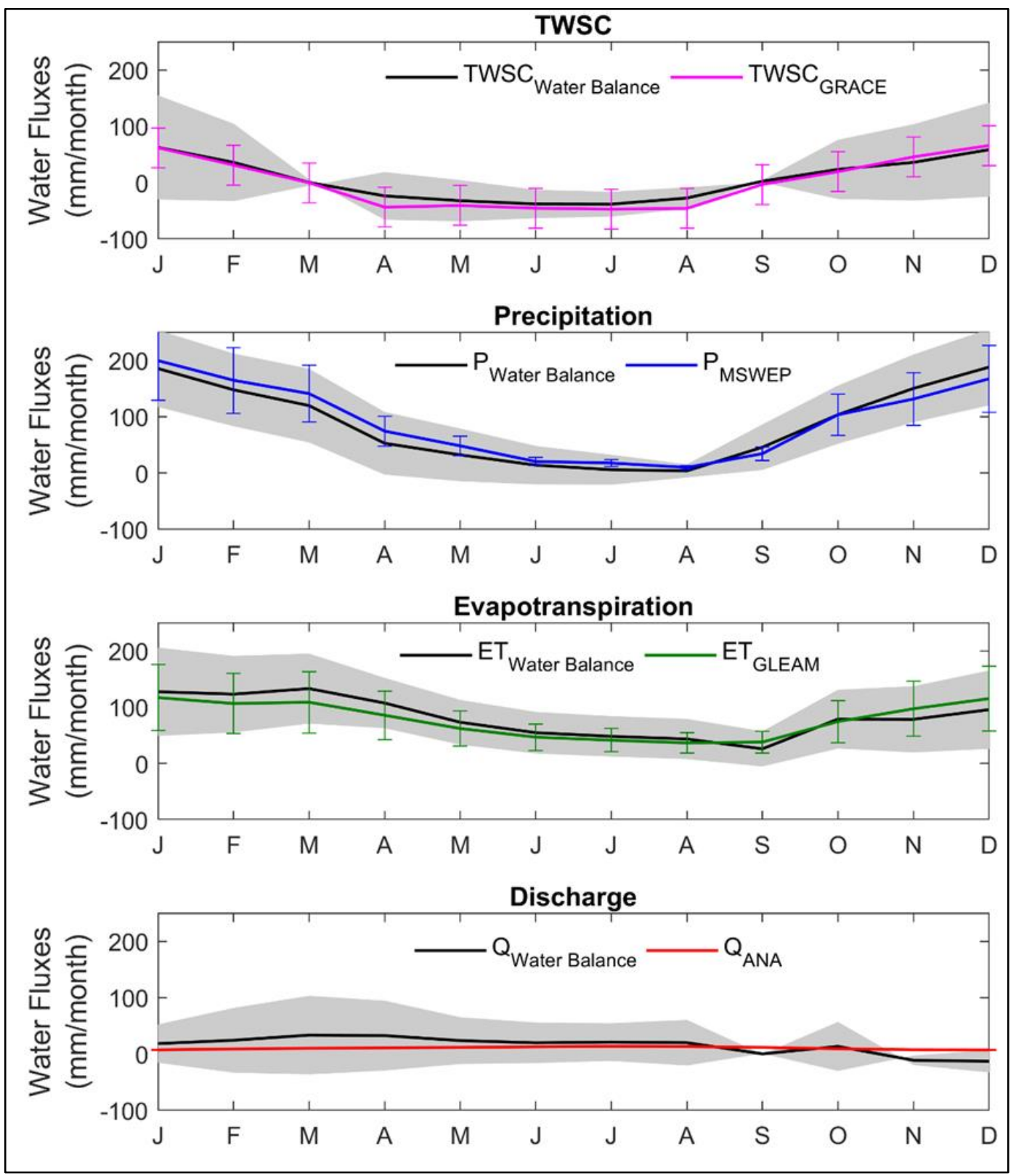

Figure 2 - Seasonal flows of precipitation, evapotranspiration, discharge and TWSC for the Upper Paraguay basin. The shaded area represents the uncertainties in each variable obtained as a residue of the water balance.

It was observed that the uncertainties in the discharge estimated by the water balance are significant, around 37.24 mm.month ${ }^{-1}$. Overestimated discharge was also obtained through the water balance for the Upper Paraguay basin (PENATTI et al., 2015), in other basins evaluated in North America (GAO et al., 2010; SHEFFIELD et al., 2009), and in the Brazilian Cerrado (OLIVEIRA et al., 2014), demonstrating that there is still a challenge in the closure of the water balance when the remote sensing approach is used.

The high values of uncertainties obtained from the water balance's variables can be reflections of both the low density of precipitation measurements and the ET, which are able to represent all the heterogeneity of the region as well as limitations in the estimation algorithms of these variables. In addition, the estimation of ET uncertainty considered the flux measurement of 


\section{REMOTE SENSING OF WATER BALANCE IN PANTANAL}

only one site. These considerations may be a limiting factor in the uncertainty estimation of the ET models, propagating greater uncertainties in the other variables estimated by the water balance.

As in other studies that evaluated the ET measured by flux site ( MACHADO et al., 2016; OLIVEIRA et al., 2006; SANCHES et al., 2011) and by remote sensing (PENATTI et al., 2015) it was verified that ET GLEAM and the ET Water Balance are able to observe the seasonality of evapotranspiration in the Pantanal system (Figure 2 ). Higher rates were observed during the rainiest months ( $\approx 101 \mathrm{~mm}$. month $^{-1}$ ET GLEAM and $\approx 106$ mm. month ${ }^{-1}$ ET Water Balance) - October to April - and lower rates during the dry season $(\approx 45$ mm.month-1 ET GLEAM and $\approx 49 \mathrm{~mm}$. month ${ }^{-1}$ ET Water Balance) - May to September. The mean annual values of ET GLEAM were similar to ET Water Balance $\left(989\right.$ and 926 mm.year ${ }^{-1}$, respectively). The annual monthly ET obtained by data from stations of the National Institute of Meteorology (INMET) in Caceres and Corumbá (Figure 1) were $995.80 \mathrm{~mm}$ year $^{-1}$ and 992.85 $\mathrm{mm}$.year ${ }^{-1}$, respectively. Although they are point measures in the northern and center regions of the Pantanal, these values show that the estimates by remote sensing reflect the average annual ET of the basin.

Figure 3 shows the relationship between ET Water balance and the ET GLEAM with climatological and environmental variables from reanalysis and remote sensing - precipitation (MSWEP), radiation (CERES - Clouds and the Earth's Radiant Energy System), air temperature (ERA Interim), relative air humidity (ERA Interim), and Enhanced Vegetation Index (EVI / MODIS).

As shown in other studies (Biudes et al., 2015, Sanches et al., 2011), the seasonality of ET presents a significant relationship with precipitation, radiation balance and vegetation index (Figure 3). It was verified in this study that the lowest ET rates are observed between May and September, when the cold air transported by the cold fronts of the south persists in the region for several days and there is a decline in the availability of surface waters. Consequently, there is a reduction of leaf area index and lower values of net radiation.

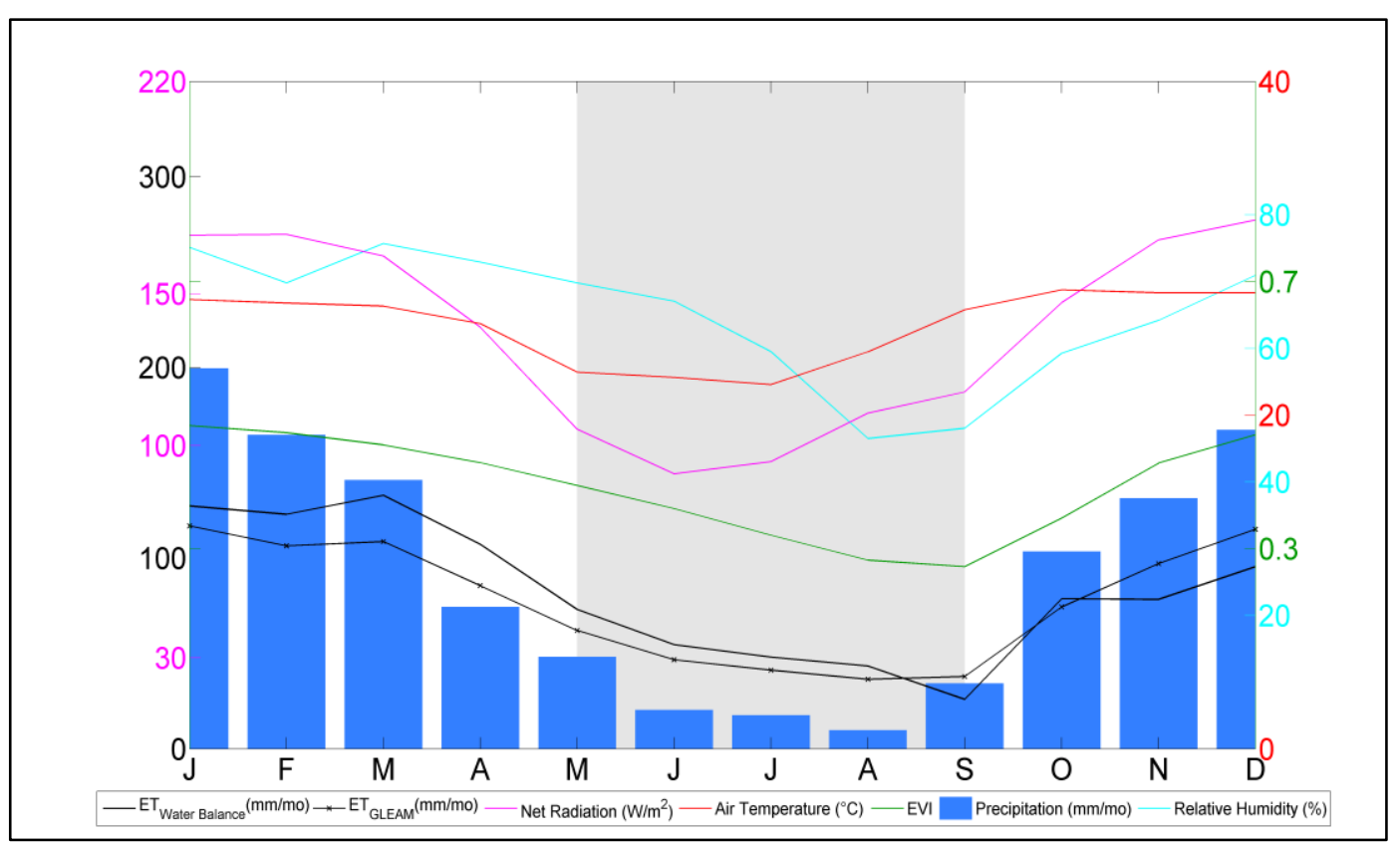

Figure 3 - Relationship between Evapotranspiration (GLEAM and Water Balance) with climatological and environmental variables. 


\section{REMOTE SENSING OF WATER BALANCE IN PANTANAL}

Considering the ET data observed in the northeast and the Mato Grosso do Sul's regions of the Pantanal, it is verified that in the dry period as well as in the rainy season, higher ET rates were noticed. As demonstrated in Oliveira et al. (2006), which studied the seasonal variations of energy flux in the Mato Grosso do Sul's Pantanal between 2000 and 2002, daily totals of $L E$ exceeded 150 $\mathrm{Wm}^{-2}$ in the rainy season and $\sim 50 \mathrm{Wm}^{-2}$ in the dry period (ET $5.28 \mathrm{~mm}$.day ${ }^{-1}$ in the rainy season and $1.76 \mathrm{~mm}$ day $^{-1}$ in the dry season). Sanches et al. (2011) also evaluated the seasonal pattern of ET in the northeast of the Pantanal and verified average values around $4 \mathrm{~mm} \cdot \mathrm{day}^{-1}$ during the rainy season and $2.5 \mathrm{~mm}$.day ${ }^{-1}$ during the dry season, with the annual total of $1,208 \mathrm{~mm}$ for 2007-2008.

From January to August, the ET water balance presented higher values than ET GLEAM (Figure 4c), while ET GLEAM was higher than that estimated by the water balance in September, November and December. The months between January and May are the ones with the greatest wetland areas in Pantanal, with a maximum in March and April (HAMILTON et al., 1996). These months demonstrated the greatest differences between ET GLEAM and ET Water balance (24.22 mm.month ${ }^{-1}$ and 21.65 mm.month ${ }^{-1}$, respectively). Penatti et al. (2015) also found underestimates in evapotranspiration using MOD16 in Pantanal. However, no studies that evaluated the accuracy of ET MOD16 and GLEAM algorithms in wetland areas were found, and this underestimation in the wet season may be related to limitation of the evaporation estimation of these models.

The average annual rainfall in the basin was of 1,112 mm.year ${ }^{-1}$, in accordance with the values presented by Ponce (1995) of 1,180 mm. year $^{-1}$ and $1,380 \mathrm{~mm}$. year ${ }^{-1}$. Such values are also close to the values obtained in the cities of Cárceres and Corumbá (INMET): 1,283 mm. year-1 and $1,060 \mathrm{~mm}$. year ${ }^{-1}$, respectively. Hamilton et. al (1998) observed that monthly precipitation exceeds ET potential from November to March (mean of months between 1977 to 1981; Thornthwaite Method) in a sub-region of Pantanal (Taquari River). The same behavior was observed for ET and precipitation in Cárceres and Corumbá. ET GLEAM is lower than precipitation from September to May/April (Figure 4e). These differences regarding the Hamilton study may be related to the differences of the analyzed periods (1977-1981 and 2003-2014) or to the ET underestimation. On the other hand, the authors also showed that there is a water deficit in the region during March that is related to water loss by evapotranspiration in floodplain lakes. In fact, it was observed that the water storage variation based on GRACE solutions is negative in March/April (Figure 4e) and with rain onset in September, storage becomes positive as in October. 


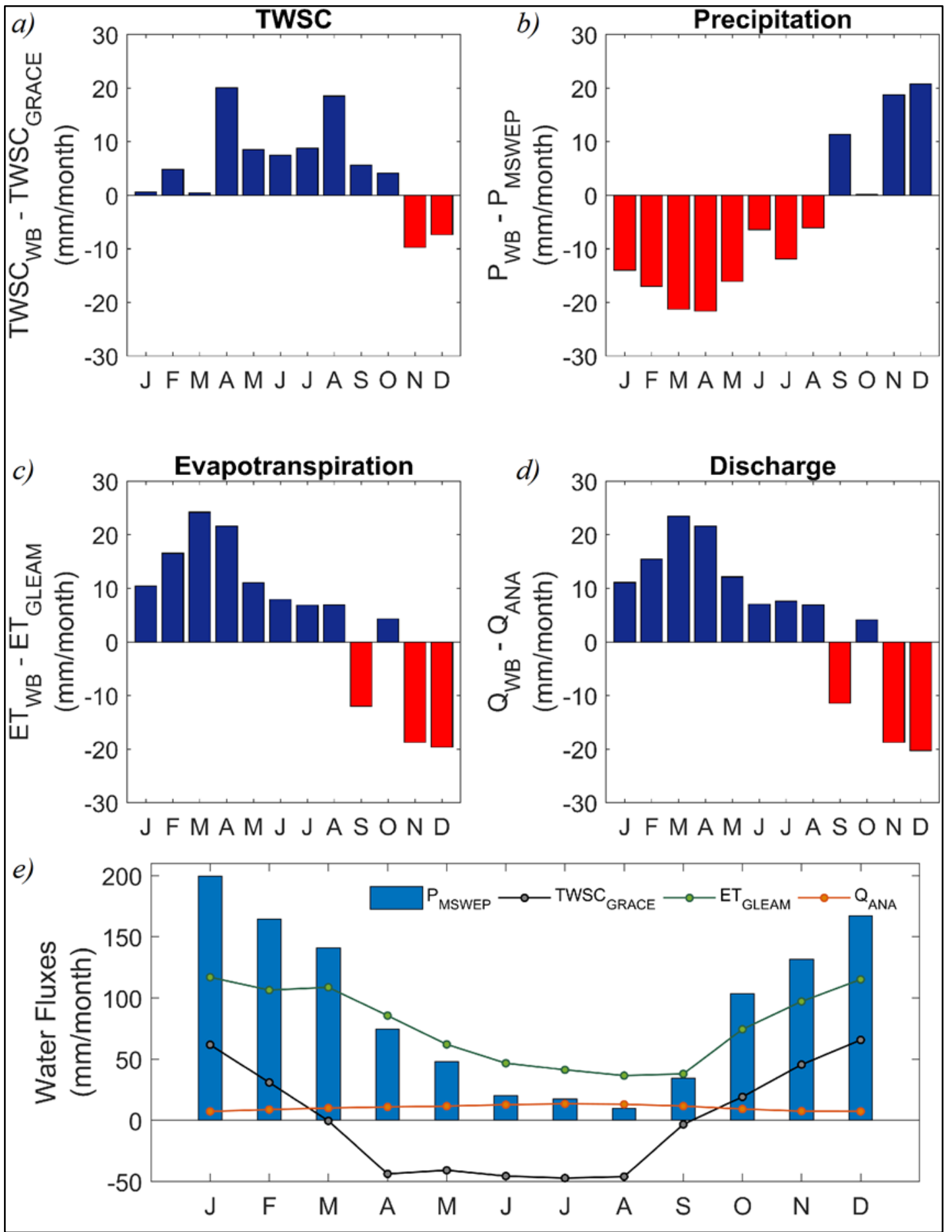

Figure 4 - Difference between the variables estimated as residue of the water balance and obtained by remote sensing (TWSC, $\mathrm{P}$ and $\mathrm{ET}$ ) or by station (Q).

Figure 5 presents the water balance variables ( $P, E T$ e TWSC) for each region of the Upper Paraguay basin. A great similarity was observed between the Pantanal and Planalto regions. In the Chaco region, the values were lower for all variables. For the MSWEP precipitation, high annual rates were observed (1,250 and 1,436 mm.year-1, respectively) in the Pantanal and Planalto regions, while the lowest annual precipitation rate was observed for the Chaco region (668 mm-1) - which is expected for this region - characterized by low precipitation 


\section{REMOTE SENSING OF WATER BALANCE IN PANTANAL}

and endorheic drainage system (PAZ et al., 2014; PENATTI et al., 2015). These results corroborate with the literature, which showed higher precipitation to the north and lower to the south of the basin (HAMILTON et al., 1998; TUCCI et al, 1999).

Higher rates of ET GLEAM were observed in the regions of Planalto $\left(1,066 \mathrm{~mm}\right.$ year $\left.^{-1}\right)$ and Pantanal (1008 mm.year ${ }^{-1}$ ), which may be related to higher rainfall rates and to the fact that $a$ flooded area is formed in Pantanal in some months of the year. The lowest rates were observed in the Chaco region (646 mm.year ${ }^{-1}$ ). Regarding the variation of water storage based on GRACE solutions, similar behavior is observed between Pantanal and Planalto regions, with positive storage between September and February (both with maximum values of $79 \mathrm{~mm}$ ). Due to the hydrological and geomorphological differences, the Chaco region presents the lowest water storage variation (maximum of $30 \mathrm{~mm}$ and minimum of $-25 \mathrm{~mm}$ ) in relation to the other regions.

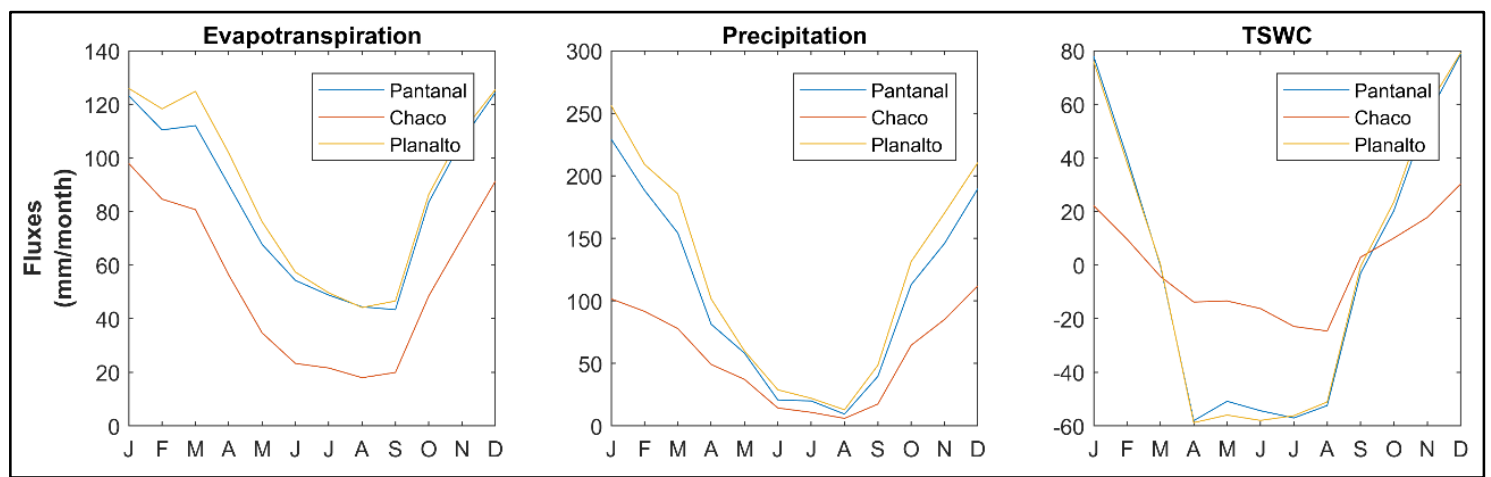

Figure 5 - Evapotranspiration (GLEAM), precipitation (MSWEP) and water storage variation (GRACE) in the Chaco, Pantanal, and Planalto regions of the Upper Paraguay basin.

\section{CONCLUSIONS}

The results indicate the potential of the remote sensing water balance approach in capturing the evapotranspiration, precipitation and storage variation behavior in the Upper Paraguay basin. It was possible to verify that the dynamics of water flows in the Pantanal system show a water deficit from March/April related to water loss through evapotranspiration, and positive water storage in October from the rains in September. Remote sensing estimates were also able to demonstrate the seasonality of water flows in different regions of the Pantanal system, confirming findings present in the literature based on in situ measurements.

For the discharge variable, it was observed an overestimation with a weak relationship between the measured and the estimated data, implying that despite the advances and improvements in the estimates of the variables of the hydrological cycle, water balance closure is still a challenge to be overcome.
High uncertainties in the variables estimates were verified, mainly during the rainy season. The low availability of measured data from both precipitation and ET was a limiting factor for the estimation of the uncertainties of the MSWEP precipitation and ET GLEAM. Therefore, this is a challenge for the knowledge of models' uncertainties in estimating hydrological cycle variables and water balance quantifications.

Despite the challenge of estimating water balance variables using remote sensing data due to coarse spatial resolution and estimation errors, this study demonstrated that these data can help in understanding the functioning of hydrological systems such as large wetlands.

\section{ACKONWLEDGEMENTS}

This research was financially supported by Coordination for the Improvement of Higher Education Personnel (CAPES), Brazil, and the Brazilian Water Agency (ANA) under grant number $88881.178687 / 2018-01$ and by the National 


\section{REMOTE SENSING OF WATER BALANCE IN PANTANAL}

Council for Scientific and Technological Development (CNPq), Brazil, process number 141979/2017-8.

\section{REFERENCES}

BORDAS M.P. The pantanal: an ecosystem in need of protection. International journal of sediment research v. 11, p. 34-39, 1996.

BECK, H. E., VERGOPOLAN, N., PAN, M., LEVIZZANI, V., VAN DIJK, A. I., WEEDON, G. P., BROCCA, L., PAPPENBERGER, F., HUFFMAN, G., WOOD, E. F.. Global-scale evaluation of 22 precipitation datasets using gauge observations and hydrological modeling. Hydrology and Earth System Sciences, v. 21, n.12, p. 6201-6217, 2017 a.

BECK, H.E. VAN DIJK, A. I., LEVIZZANI, V., SCHELLEKENS, J., GONZALEZ MIRALLES, D., MARTENS, B., \& DE ROO, A.. MSWEP: 3-hourly 0.25 global gridded precipitation (1979-2015) by merging gauge, satellite, and reanalysis data. Hydrology and Earth System Sciences, v. 21, n. 1 , p. 589-615, 2017b.

FISHER, J. B., MELTON, F., MIDDLETON, E., HAIN, C., ANDERSON, M., ALLEN, R., ... \& KILIC, A.. The future of evapotranspiration: Global requirements for ecosystem functioning, carbon and climate feedbacks, agricultural management, and water resources. Water Resources Research, v.53, n. 4, p. 2618-2626, 2017.

GAO, H. TANG, Q., FERGUSON, C. R., WOOD, E. F., \& LETTENMAIER, D. P.. Estimating the water budget of major US river basins via remote sensing. International Journal of Remote Sensing, v. 31, n. 14, p. 3955-3978, 2010.

HAMILTON, S. K.; DE SOUZA, O C; COUTINHO, M E. Dynamics of floodplain inundation in the alluvial fan of the Taquari River (Pantanal, Brazil). Internationale Vereinigung für theoretische und angewandte Limnologie: Verhandlungen, v. 26, n. 3, p. 916-922, 1998.
HAMILTON, S. K.; SIPPEL, S. J.; MELACK, J. M. Inundation patterns in the Pantanal wetland of South America determined from passive microwave remote sensing. Archiv für Hydrobiologie, v. 137, n. 1, p. 1-23, 1996.

HAMILTON, S K. Hydrological controls of ecological structure and function in the Pantanal wetland (Brazil). The Ecohydrology of South American Rivers and Wetlands. International Association of Hydrological Sciences, Special Publication, v. 6, p. 133-158, 2002.

LANDERER, Felix W.; SWENSON, S. C. Accuracy of scaled GRACE terrestrial water storage estimates. Water resources research, v. 48, n. 4, p. 1-11, 2012.

LONG, D; LONGUEVERGNE, L; SCANLON, B R. Uncertainty in evapotranspiration from land surface modeling, remote sensing, and GRACE satellites. Water Resources Research, v. 50, n. 2, p. 1131-1151, 2014.

MACHADO, N G, BIUDES, M. S., ANGELINI, L. P., SOUZA, D. M. S., NASSARDEN, D. C. S., BILIO, R. S., ... \& NOGUEIRA, J. S.. Sazonalidade do Balanço de Energia e Evapotranspiração em Área Arbustiva Alagável no Pantanal Mato-Grossense. Revista Brasileira de Meteorologia, v. 31, n. 1, p. 82-91, 2016.

MAEDA, E. E. MA, X., WAGNER, F. H., KIM, H., OKI, T., EAMUS, D., \& HUETE, A. Evapotranspiration seasonality across the Amazon Basin. Earth System Dynamics, v. 8, n. 2, p. 439-454, 2017.

MARTENS, B., GONZALEZ MIRALLES, D., LIEVENS, H., VAN DER SCHALIE, R., De JEU, R. A., FERNÁNDEZ-PRIETO, D., ... \& Verhoest, N.. GLEAM v3: satellite-based land evaporation and root-zone soil moisture, Geoscientific Model Development, v. 10, n.5, p.1903-1925. 2017.

MIRALLES, D. G., HOLMES, T. R. H., De Jeu, R. A. M., GASH, J. H. C., MEESTERS, A. G. C. A., \& DOLMAN, A. J.. Global land-surface evaporation estimated from satellite-based observations. Hydrology and Earth System Sciences, v. 15, n. 2, p. 453-469, 2011. 


\section{REMOTE SENSING OF WATER BALANCE IN PANTANAL}

MIRALLES, D. G., JIMENEZ, C. JUNG, M., MICHEL, D. ERSHADI, A., MCCABE, M. F., HIRSCHI, M., MARTENS, B., DOLMAN, A. J., FISHER, J. B., MU, Q., SENEVIRATNE, S. I., WOOD, E. F., FERNANDEZPRIETO, D.. The WACMOS-ET project - Part 2: Evaluation of global terrestrial evaporation data sets. Hydrology and Earth System Sciences, v. 20, n. 2, p. 823-843, 2016.

MU, Q.; ZHAO, M.; RUNNING, S. W. Improvements to a MODIS global terrestrial evapotranspiration algorithm. Remote Sensing of Environment, v. 115, n. 8, p. 1781-1800, 2011.

OLIVEIRA, M. B., , MANZI, A. O., MARIO de MIRANDA, V. B. R., de SOUZA, A., dos SANTOS ALVALÁ, R. C., de ABREU Sá, L. D., \& VON RANDOW, C.. Fluxos turbulentos de energia sobre o Pantanal sul mato-grossense. Revista Brasileira de Meteorologia. v. 21, n. 3b, p. 371-377, 2006.

OLIVEIRA, P. T. S., NEARING, M. A., MORAN, M. S., GOODRICH, D. C., WENDLAND, E., \& GUPTA, H. V.. Trends in water balance components across the Brazilian Cerrado. Water Resources Research, v. 50, n. 9, p. 7100-7114, 2014.

PAZ, A. R., COLLISCHONN, W., BRAVO, J. M., BATES, P. D., \& BAUGH, C. . The influence of vertical water balance on modelling Pantanal (Brazil) spatio-temporal inundation dynamics. Hydrological processes, v. 28, n. 10, p. 3539-3553, 2014.

PAZ, A. R., BRAVO, J. M., ALLASIA, D., COLLISCHONN, W., \& TUCCI, C. E. M.. Large-scale hydrodynamic modeling of a complex river network and floodplains. Journal of hydrologic engineering, v. 15, n. 2, p. 152-165, 2010.

PENATTI, N. C., de ALMEIDA, T. I. R., FERREIRA, L. G., ARANTES, A. E., \& COE, M. T.. Satellite-based hydrological dynamics of the world's largest continuous wetland. Remote Sensing of Environment, v. 170, p. 1-13, 2015.

PONCE, V. M. Hydrologic and environmental impact of the Paraná-Paraguay waterway on the Pantanal of Mato Grosso, Brazil: A reference study. San Diego State University, 1995. Disponível em.
PRIESTLEY, C. H. B.; TAYLOR, R. J. On the assessment of surface heat flux and evaporation using large-scale parameters. Monthly weather review, v. 100, n. 2, p. 81-92, 1972.

RODELL, M., FAMIGLIETTI, J. S., CHEN, J., SENEVIRATNE, S. I., VITERBO, P., HOLL, S., \& WILSON, C. R.. Basin scale estimates of evapotranspiration using GRACE and other observations. Geophysical Research Letters, v. 31, n. 20, p. 10-13, 2004.

RODELL M., MCWILLIAMS, E. B., FAMIGLIETTI, J. S., BEAUDOING, H. K., \& NIGRO, J.. Estimating evapotranspiration using an observation based terrestrial water budget. Hydrological Processes, v. 25, n. 26, p. 4082-4092, 2011.

SAKUMURA, C.; BETTADPUR, S.; BRUINSMA, S. Ensemble prediction and intercomparison analysis of GRACE time-variable gravity field models. Geophysical Research Letters, v. 41, n. 5, p. 1389-1397, 2014.

SANCHES, L. VOURLITIS, G. L., de CARVALHO ALVES, M., PINTO-JÚNIOR, O. B., \& de NOGUEIRA, J. S.. Seasonal patterns of evapotranspiration for a Vochysia divergens forest in the Brazilian Pantanal. Wetlands, v. 31 , n. 6, p. $1215-1225$, 2011.

SENAY, G. B., LEAKE, S., NAGLER, P. L., ARTAN, G., DICKINSON, J., CORDOVA, J. T., \& GLENN, E. P.. Estimating basin scale evapotranspiration (ET) by water balance and remote sensing methods. Hydrological Processes, v. 25, n. 26, p. 4037-4049, 2011.

SHEFFIELD, J., FERGUSON, C. R., TROY, T. J., WOOD, E. F., \& McCABE, M. F. . Closing the terrestrial water budget from satellite remote sensing. Geophysical Research Letters, v. 36, n. 7, p. 1-5, 2009.

SHUTTLEWORTH, W. James. Terrestrial hydrometeorology. John Wiley \& Sons, 2012.

SWANN, A. L. S. and KOVEN, C. D. A direct estimate of the seasonal cycle of evapotranspiration over the Amazon basin. Journal of Hydrometeorology, v. 18, n. 8, p. 2173-2185, 2017. 


\section{REMOTE SENSING OF WATER BALANCE IN PANTANAL}

SWENSON, Sean; WAHR, John. Post-processing removal of correlated errors in GRACE data. Geophysical Research Letters, v. 33, n. 8, p. 1-4, 2006.

TAPLEY, B. D.,, , BETTADPUR, S., WATKINS, M., \& REIGBER, C. The gravity recovery and climate experiment: Mission overview and early results. Geophysical Research Letters, v. 31, n. 9, 2004.

TUCCI CEM, GENZ F, CLARKE RT. Hydrology of the upper Paraguay basin. In Management of Latin American River Basins: Amazon, Plata and São Francisco, Biswas K, Cordeiro N, Braga B, Tortajada C (eds). United Nations University Press: Tokyo, 1999.

ZHANG, Y., PAN, M., SHEFFIELD, J., SIEMANN, A. L., FISHER, C. K., LIANG, M., ... \& ZHOU, T. . A Climate Data Record (CDR) for the global terrestrial water budget: 1984-2010. Hydrology and Earth System Sciences, v. 22, n. 1, p. 241-263, 2018. 